\title{
Synthesis and inclusion of $S$-aryl alkylthiosulfinates as stable allicin mimics
}

\author{
Nashia Stellenboom, Roger Hunter,* Mino R. Caira, Susan A. Bourne, Khethiwe Cele, \\ Tozama Qwebani, and Tanya le Roex \\ Chemistry Department, University of Cape Town, Rondebosch, 7701, CapeTown, South Africa \\ E-mail: roger@science.uct.ac.za
}

\section{Dedicated to Professor Berhanu M Abegaz on the occasion of his $60^{\text {th }}$ birthday}

\begin{abstract}
$S$-Aryl alkylthiosulfinates showing aromatic rings with varying electronic demand have been prepared by oxidation of the corresponding disulfide, the latter prepared using new one-pot methodology involving thiol oxidation with 1-chlorobenzotriazole. Whereas thiosulfinates with electron-withdrawing substituents in the aromatic ring were unstable towards isolation, those with a releasing substituent in the para-position have shown good stability as potential allicin mimics and one of them ( $p$-OMe) has been characterised as its inclusion compound in the cyclodextrin, TRIMEB, by X-ray crystallography.
\end{abstract}

Keywords: Allicin mimic, unsymmetrical disulfide synthesis, $S$-aryl alkylthiosulfinate, cyclodextrin inclusion

\section{Introduction}

Modern organic chemistry has played a major role in elucidating the fascinating chemistry that goes on when a garlic clove is crushed or attacked by a pathogen to produce the thiosulfinate allicin, Figure 1.

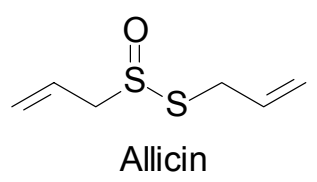

Figure 1 
The folklore and therapeutic benefits of garlic are legendary, dating back about five thousand years, and in recent times several in vitro studies have demonstrated allicin to have potent antibacterial, antifungal and antiparasitic activity against a range of microorganisms including methicillin-resistant Staphylococcus aureus. ${ }^{2,3}$ Antiviral activity has also been demonstrated, ${ }^{4}$ but synthetic allicin, obtained either biomimetically or chemically from diallyl disulfide has never been developed for human use in vivo as a result of its instability. ${ }^{2}$ We have recently initiated a medicinal chemistry programme aimed at developing stable allicin mimics as potentially new antimicrobial agents. The target mimics were chosen as $S$-aryl alkylthiosulfinates, which we expected to retain the prospect of biological activity based on the established finding that the thiosulfinate grouping acts as an electrophilic pharmacophore for sulfhydryl groups of thiols resulting in their oxidation to disulfides. ${ }^{5}$ Regarding the question of stability, structural features in the targets were chosen to preclude the possibility of breakdown via a Block-type fragmentation established for allicin, ${ }^{6}$ which produces thioacrolein and 2propenesulfenic acid, the former subsequently dimerizing to 1,2- and 1,3-dithiins. Of crucial importance regarding this fragmentation reaction is the presence of an allylic hydrogen adjacent to the sulfenyl sulphur (shown in the scheme). Alternatively, allicin may rearrange to ajoene ${ }^{6 c, 7}$ also involving the same hydrogen, Scheme 1.

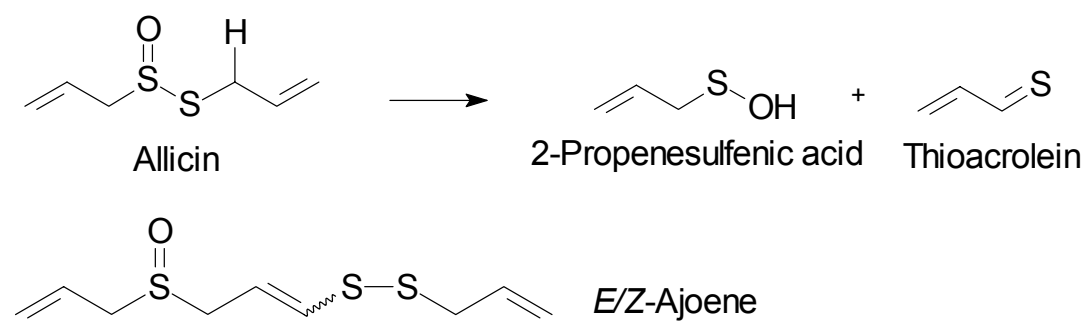

\section{Scheme 1}

Thus, it was decided to replace the sulfenyl allyl group of allicin with an aromatic ring lacking a $\beta$-hydrogen in order to inhibit the initial fragmentation. The substitution would invite the possibility of aromatic ring substitutions for attenuating electrophilicity at the sulfenyl sulfur; heteroaromatic changes could also be considered in the same vein. On the sulfinyl sulphur side, we decided to stay with an aliphatic group in view of the known tendency of diarylthiosulfinates to disproportionate. ${ }^{8}$ Figure 2 summarises our SAR motif for the target $S$-aryl alkylthiosulfinates 1 .

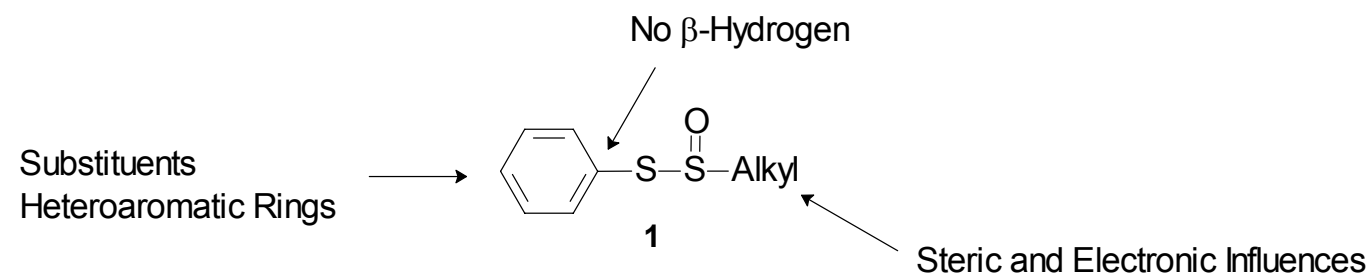

\section{Figure 2}


On the prospect of achieving enhanced stability, we were also encouraged by the recent paper by Brace ${ }^{9}$ on the fluorinated thiosulfinate $\mathbf{2}$ shown in Figure 3, which shows a significantly increased stability compared to its hydrogenated analogue.

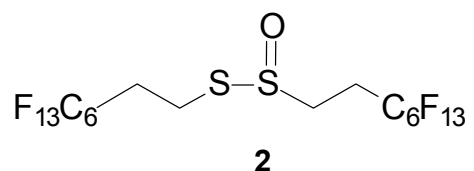

\section{Figure 3}

In this paper we report on the synthesis of aralkyl disulfides with either an electronreleasing or withdrawing group in the aromatic ring, and their oxidation to the corresponding thiosulfinate using $m$-CPBA. ${ }^{10}$ In addition, inclusion is described for one of the thiosulfinates into the permethylated $\beta$-cyclodextrin, TRIMEB.

\section{Results and Discussion}

We have recently reported ${ }^{11}$ novel methodology for unsymmetrical disulfide synthesis involving a one-pot oxidation with 1-chlorobenzotriazole $(\mathrm{BtCl})$. The general sequence of events is shown in Scheme 2.

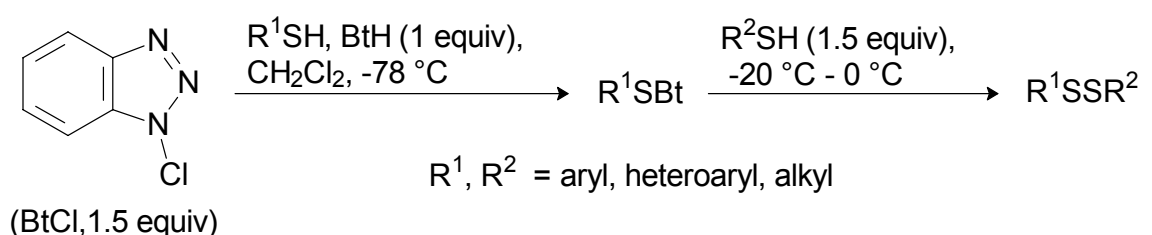

\section{Scheme 2}

This methodology was put to good use in preparing a range of disulfides for studying their oxidation to the thiosulfinate. Each case had $\mathrm{R}^{1}$ as either an aromatic or pyridyl heteroaromatic ring, and $\mathrm{R}^{2}$ as an alkyl chain. Each aromatic ring contained a substituent ortho or para to the sulfur for the expected attenuation of stability of target thiosulfinate. We decided to replace the allyl group of allicin with a fully saturated alkyl chain, as it was anticipated that this would not drastically affect any biological activity. Moreover, it had already been shown that yields of arallyl disulfides were significantly lower than those of the aralkyl systems. Table 1 shows the structures synthesized together with the yield of each after chromatography. 
Table 1. Yields for disulfides from $\mathrm{BtCl}$ methodology

\begin{tabular}{|c|c|c|c|}
\hline Entry & $\mathrm{R}^{1} \mathrm{SSR}^{2}$ Product & Compound & Yield $(\%)$ \\
\hline 1 & & 3 & $91^{\mathrm{a}}$ \\
\hline 2 & & 4 & $85^{\mathrm{b}}$ \\
\hline 3 & & 5 & 82 \\
\hline 4 & & 6 & 90 \\
\hline 5 & & 7 & 88 \\
\hline 6 & $-\mathrm{N}$ & 8 & $84^{\mathrm{c}}$ \\
\hline
\end{tabular}

${ }^{a}$ Reported in reference $11 \mathrm{a}$ and $11 \mathrm{~b},{ }^{\mathrm{b}}$ reported in reference $11 \mathrm{c},{ }^{\mathrm{c}}$ reported in reference $11 \mathrm{~d}$.

Consistent with our previous study, ${ }^{11 \mathrm{~b}}$ it was found that higher yields were obtained adding the aromatic thiol first, as the other way round resulted in the formation of large amounts of the aliphatic disulfide homodimer. Each product was fully characterised by both ${ }^{1} \mathrm{H}$ and ${ }^{13} \mathrm{C}$ NMR to reveal the expected resonances, with the $\alpha$-methylene protons and carbon diagnostic at $\sim \delta=2.7$ ppm and $40 \mathrm{ppm}$ for the two respective spectra.

We have previously reported a preliminary study regarding the oxidation of $p$ methoxyphenyl propyl disulfide using $m$-CPBA (1 equivalent) at low temperature, ${ }^{11 \mathrm{a}}$ in which oxidation took place chemoselectively at the more nucleophilic sulfur attached to the aliphatic group (alk) to form the desired thiosulfinate, as evidenced by ${ }^{1} \mathrm{H}$ NMR and ${ }^{13} \mathrm{C}$ NMR shifts pertaining to the $\alpha$-alkyl carbon. In addition, some thiosulfonate was also obtained. Scheme 3 .

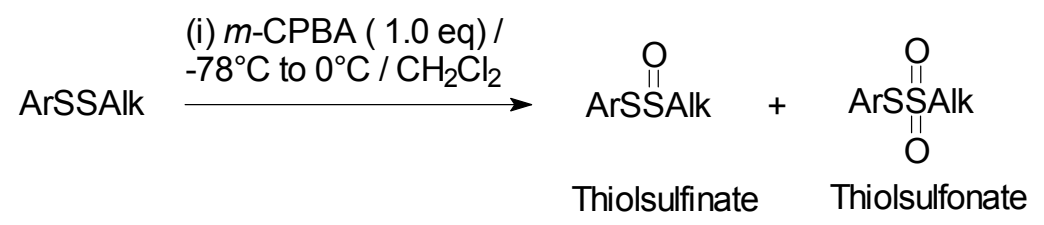

\section{Scheme 3}

In extending this study, it was found that marked differences between the substrates were observed, Table 2. For entries 2 and 3, oxidation occurred with similar profiles to those in the previous study already mentioned to produce 3a. ${ }^{11 \text { a }}$ Thus, the $S$-aryl alkylthiosufinates $\mathbf{4 a}$ and $\mathbf{5 a}$ were obtained in good yield together with some thiosulfonate by-product as before. Assignment 
of the regiochemistry of oxidation was based on comparison of the NMR data with that of compound 3a as described previously. ${ }^{11 a}$ The thiosulfinates were successfully chromatographed and found to have high stability at room temperature (see Table 3 ). Conversely, both compounds with electron-withdrawing substituents in the aromatic ring $\mathrm{R}^{1}\left(\mathrm{CO}_{2} \mathrm{Me}\right.$ and $\mathrm{NO}_{2}$; entries 4 and 5 respectively), although producing a major product on tlc, failed to produce anything on purification involving a conventional work-up and chromatography. Tlc analysis of the column fractions revealed multiple spots indicating extensive breakdown. This strongly suggests that electron deficiency in the aromatic ring leads to instability of the thiosulfinate, precluding them as potential allicin mimics. Interestingly, the heteroaromatic pyridyl case (entry 6) gave an altogether different result. In spite of its aromatic ring being highly electron-withdrawing towards the sulfur atoms, oxidation proceeded to form two products that were stable to isolation by chromatography. The more polar of the two proved to be pyridyl disulfide, as evidenced by tlc, melting point and its ${ }^{1} \mathrm{H}$ NMR spectrum compared with an authentic sample. The less polar of the two products has a structure that has not been elucidated beyond reasonable doubt as yet but is clearly not $S$-pyridyl propylthiosulfinate as evidenced by ${ }^{1} \mathrm{H}$ and ${ }^{13} \mathrm{C}$ NMR spectra, which indicate the presence of three propyl groups in the ratio1:1:1 and each one in a significantly different chemical environment. Furthermore, NMR shifts indicate the pyridine nitrogen to be unoxidized. The structural elucidation of this interesting rearrangement will be reported elsewhere. An overview of the oxidation results is presented in Table 2.

Table 2: Oxidation of unsymmetrical disulfides to thiosulfinates

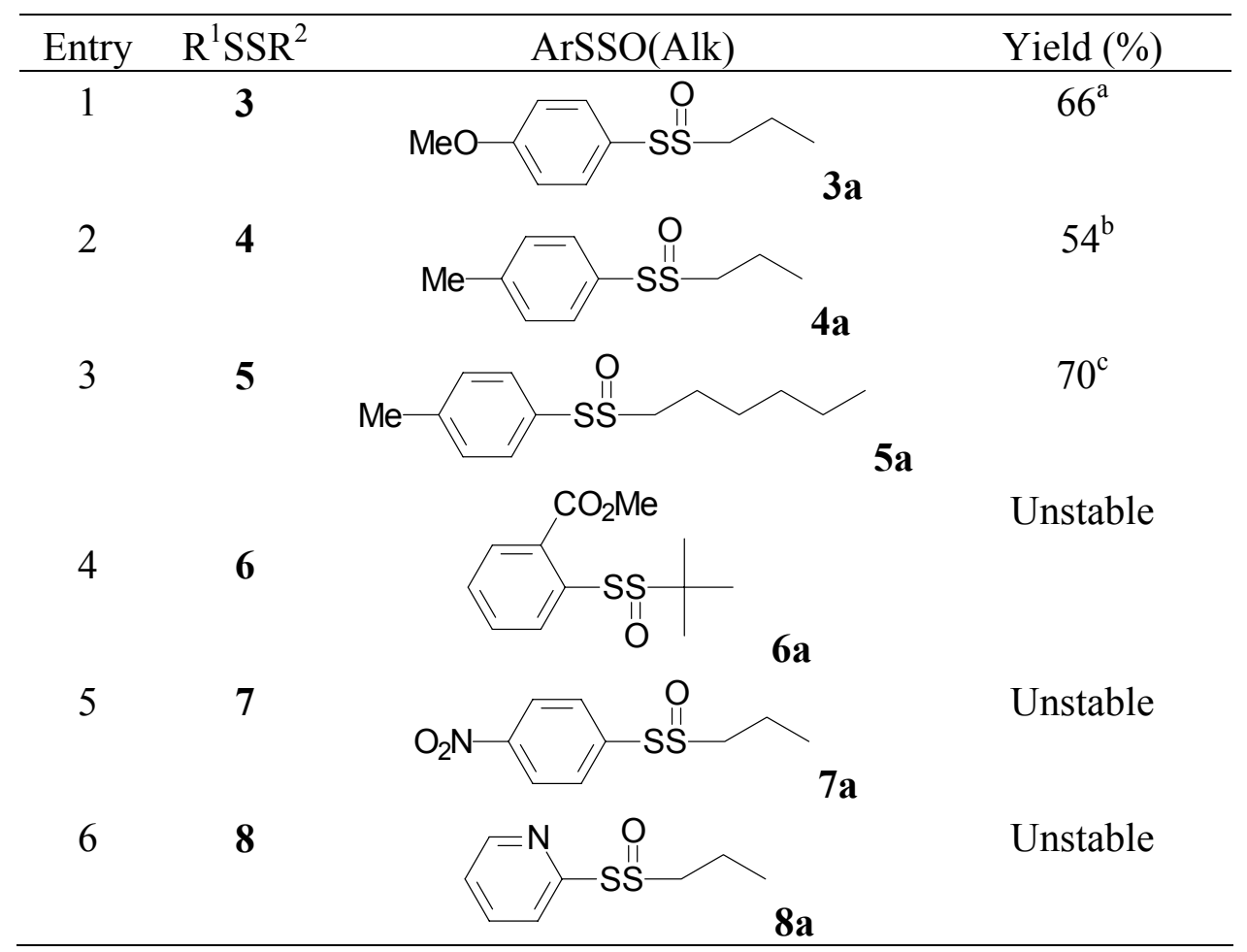

${ }^{a}$ With $23 \%$ of thiosulfonate; ${ }^{b}$ With $14 \%$ of thiosulfonate; ${ }^{c}$ With $15 \%$ of thiosulfonate 
Regarding stability studies, samples of the thiosulfinates $\mathbf{3 a}$ and $\mathbf{4 a}$ were left at room temperature (around $20^{\circ} \mathrm{C}$ ) on the bench in a neat form, in the refrigerator $\left(-5^{\circ} \mathrm{C}\right)$ in a neat form and in solution $\left(\mathrm{CDCl}_{3}\right)$ at room temperature. $400 \mathrm{MHz}{ }^{1} \mathrm{H}$ NMR spectroscopy was used to evaluate the \% conversion after 1, 3 and 5 months, using signals in the aromatic and methyl regions. After 1 month neat at room temperature, less than 5\% decomposition was noted for the samples. This contrasts with allicin, which has a half-life of 16 hours under the same conditions. Both thiosulfinates proved to be significantly more stable in the neat form at room temperature than in solution in $\mathrm{CDCl}_{3}$, Table 3. Tlc indicated the decomposition to involve disproportionation $^{8}$ to the corresponding disulfide and thiosulfonate according to reference samples. Interestingly, the results indicate that whilst $\mathbf{3 a}$ is more stable than $\mathbf{4 a}$ in the neat form, the reverse applies in solution.

Table 3: Decomposition studies of thiosulfinates 3a and 4a

\begin{tabular}{ccccccc}
\hline Cpd & Time $^{\mathrm{a}}$ & $0^{\circ} \mathrm{C}^{\mathrm{b}, \mathrm{c}}$ & Time & $\mathrm{RT}^{\mathrm{b}, \mathrm{c}}$ & Time & $\mathrm{RT}, \mathrm{CDCl}_{3}{ }^{\mathrm{b}}$ \\
\hline $\mathbf{3 a}$ & 1 & $<1$ & 1 & $<3$ & 1 & 60 \\
$\mathbf{3 a}$ & 3 & $<3$ & 3 & $\mathrm{~d}$ & 3 & 100 \\
$\mathbf{3 a}$ & 5 & 10 & 5 & 50 & 5 & $\mathrm{~d}$ \\
& & & & & & \\
$\mathbf{4 a}$ & 1 & $<5$ & 1 & 5 & 1 & 10 \\
$\mathbf{4 a}$ & 3 & 6 & 2 & 12 & 3 & 75 \\
$\mathbf{4 a}$ & 5 & 15 & 5 & 75 & 5 & $\mathrm{~d}$ \\
\hline${ }^{\mathrm{a}}$ In Months; ${ }^{\mathrm{b}}$ as a $\%$ of conversion determined by $400 \mathrm{MHz}^{1} \mathrm{H}$ NMR; ${ }^{\mathrm{c}}$ Neat; ${ }^{\mathrm{d}}$ Not recorded
\end{tabular}

Following our successful inclusion of the isomers of ajoene in cyclodextrins, ${ }^{12}$ it was of interest to establish whether the novel $S$-aryl alkylthiosulfinates would show a similar affinity for these host molecules. The oxidation product of entry 1 (Table 2), namely $S$ - $p$-methoxyphenyl propylthiosulfinate $\mathbf{3 a}$, as a representative of this series, was accordingly added to a saturated aqueous solution of an equimolar amount of heptakis(2,3,6-tri-O-methyl)- $\beta$-cyclodextrin (TRIMEB) and the mixture stirred in a vial for $24 \mathrm{~h}$. Following incubation of the vial at $50^{\circ} \mathrm{C}$ for $72 \mathrm{~h}$, colourless prismatic crystals of the inclusion compound appeared. These were harvested and characterised by elemental analysis, hot stage microscopy (HSM), thermogravimetry (TGA), differential scanning calorimetry (DSC) and single crystal X-ray diffraction, as described below.

Elemental analysis yielded $\% \mathrm{C} 52.2, \% \mathrm{H} 7.4, \% \mathrm{~S} 3.9$, consistent with $1: 1$ host-guest stoichiometry (calcd. for $\mathrm{C}_{63} \mathrm{H}_{112} \mathrm{O}_{35} \cdot \mathrm{C}_{10} \mathrm{H}_{14} \mathrm{O}_{2} \mathrm{~S}_{2}$ : \% $52.82, \% \mathrm{H}$ 7.65, \% 3.86 ). HSM revealed melting of the complex crystals at $\sim 134^{\circ} \mathrm{C}$. In the DSC trace, onset and peak temperatures corresponding to the melting endotherm were recorded as 132.6 and $136.9^{\circ} \mathrm{C}$ respectively. The TGA trace showed negligible mass loss in the temperature range $25-160{ }^{\circ} \mathrm{C}$ followed by a mass loss of $\sim 13.2 \%$ between 160 and $325^{\circ} \mathrm{C}$. The latter corresponds to release of the guest from the inclusion complex (calcd. for 1:1 host-guest stoichiometry $13.9 \%$ ). Above $325^{\circ} \mathrm{C}$, the host 
compound decomposed. Details of the X-ray analysis are listed in the experimental Section and in Table 4.

Table 4. Crystal data and details of refinement for the complex TRIMEB-(S)-S-p-methoxyphenyl propylthiosulfinate $^{\mathrm{a}}$

\begin{tabular}{ll}
\hline Complex formula & $\mathrm{C}_{63} \mathrm{H}_{112} \mathrm{O}_{35} \cdot \mathrm{C}_{10} \mathrm{H}_{14} \mathrm{O}_{2} \mathrm{~S}_{2}$ \\
$M$ & 1659.88 \\
Crystal system & Orthorhombic \\
Space group & $\mathrm{P} 2{ }_{1}{ }_{1} 2_{1}$ \\
$a / \AA$ & $14.7750(2)$ \\
$b / \AA$ & $21.3329(3$ \\
$c / \AA$ & $27.872(1)$ \\
$V_{\text {cell }} \AA^{3}$ & $8785.2(4)$ \\
$\mathrm{Z}$ & 4 \\
$T / \mathrm{K}$ & $113(2)$ \\
Absorption coefficient/mm & \\
$\mathrm{F}(000)$ & 0.145 \\
Theta range & 3568 \\
Index ranges & $2.8-25.7$ \\
Reflections collected & $-17 \leq \mathrm{h} \leq 18,-25 \leq \mathrm{k} \leq 26,-33 \leq 1 \leq 33$ \\
Observed reflections $[\mathrm{I}>2 \sigma(\mathrm{I})]$ & 11196 \\
Data/parameters & $16562 / 939$ \\
Goodness-of-fit on $\mathrm{F}^{2}$ & 1.04 \\
Final R indices $[\mathrm{I}>2 \sigma(\mathrm{I})]$ & $\mathrm{R} 1=0.0877, \mathrm{wR}_{2}=0.2674$ \\
Largest diff. peak and hole & $-0.96,1.58 \mathrm{e} \AA^{-3}$ \\
\hline
\end{tabular}

${ }^{a}$ Full crystallographic data (CCDC 616365)

A perspective view of the complex structure is shown in Figure 4, with the host in balland-stick mode and the guest in space-filling representation. The TRIMEB molecule displays the usual elliptical distortion, ${ }^{12}$ stabilised by several C-H...O hydrogen bonds, with the methoxyl groups on the primary rim acting as a lid, presenting the guest with a cup-shaped hydrophobic surface for inclusion. The guest molecule adopts a hairpin conformation with the moiety $-\mathrm{S}-\mathrm{S}=\mathrm{O}$ located near the cavity 'roof' and the methoxyphenyl and propyl residues directed towards the secondary rim of the host molecule.

Interestingly, in each of the TRIMEB inclusion complexes of $(E)$ - and (Z)-ajoene, a disordered arrangement, comprising both the $R$ - and $S$-enantiomers of the guest, was identified within the host cavity. ${ }^{12}$ In contrast, for the crystal selected, only the $S$-enantiomer of $S$ - $p$ methoxyphenyl propylthiosulfinate was evident in the present complex. 


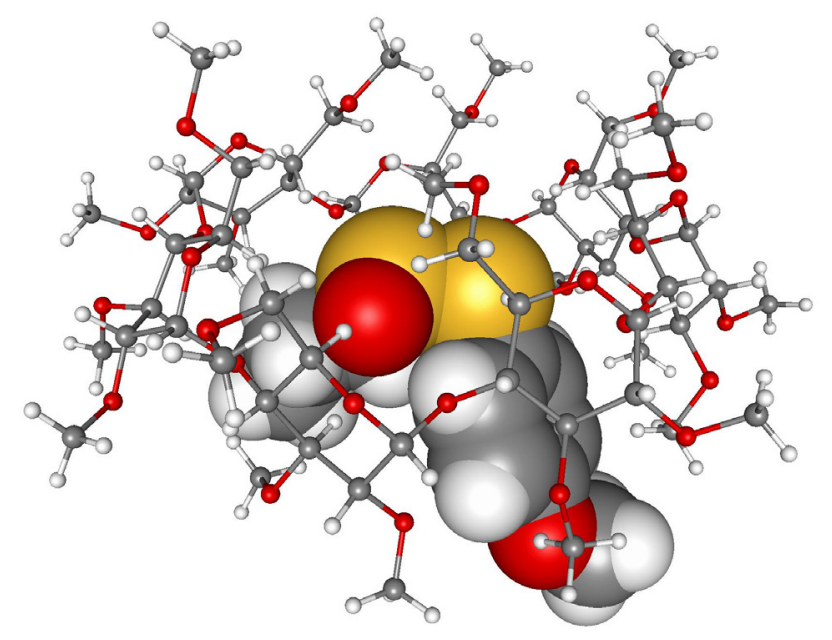

Figure 4. Molecular structure of the complex TRIMEB.(S)-S-p-methoxyphenyl propylthiolsulfinate

In summary, the present study opens up the way for further work to be carried out on $S$ aryl alkylthiosulfinates bearing electron-releasing groups in the aromatic ring, with the emphasis on investigating potential biological activity and associated structure-activity relationships. Work will also continue towards attempting to produce even more stable thiosulfinates of this type, ${ }^{13}$ with the incorporation of fluorinated alkylsulfinyl groups an attractive option to pursue. ${ }^{9}$

\section{Acknowledgements}

We thank the National Research Foundation for funding.

\section{Experimental Section}

General Procedures. Thin layer chromatography (Tlc) was used to monitor reactions using aluminium-backed plates coated with Merck silica-gel $\mathrm{F}_{254}$. Compounds on tlc plates were observed by UV lamp and iodine vapour. Column chromatography was performed using Merck silica-gel 60-230 mesh. Melting points were measured on a Reichert-Jung Thermovar hot-stage microscope. Infrared spectra were recorded on sodium chloride plates on a Perkin-Elmer Paragon 1000 FT-IR spectrophotometer. High resolution mass spectrometry data was obtained using a VG70-SEQ micromass spectrometer. ${ }^{1} \mathrm{H}$ and ${ }^{13} \mathrm{C}$ NMR spectra were recorded on either a Varian VXR-300 (at $300.08 \mathrm{MHz}$ for ${ }^{1} \mathrm{H}$ and $75.5 \mathrm{MHz}$ for ${ }^{13} \mathrm{C}$ ) or a Varian Unity 400 (at 399.95 $\mathrm{MHz}$ for ${ }^{1} \mathrm{H}$ and $100.58 \mathrm{MHz}$ for ${ }^{13} \mathrm{C}$ ) spectrometer in deuteriochloroform $\left(\mathrm{CDCl}_{3}\right)$. Chemical 
shifts are quoted using residual chloroform ( $\delta 7.24$ in ${ }^{1} \mathrm{H}$ NMR and $\delta 77.00$ in ${ }^{13} \mathrm{C}$ NMR) as an internal standard. All chemical shifts are reported in ppm and all coupling constants are quoted in Hz. All solvents were purified using standard methods and freshly distilled.

The unsymmetrical disulfides were synthesized using the following method ${ }^{11 \mathrm{~b}}$. To a stirred solution of 1-chlorobenzotriazole $(0.46 \mathrm{~g}, 3 \mathrm{mmol})$ and benzotriazole $(0.24 \mathrm{~g}, 2 \mathrm{mmol})$ in $\mathrm{CH}_{2} \mathrm{Cl}_{2}$ $(10 \mathrm{ml})$ under $\mathrm{N}_{2}$ at $-78^{\circ} \mathrm{C}$ was added weighed thiol $\mathrm{R}^{1} \mathrm{SH}(2 \mathrm{mmol})$ dissolved in $\mathrm{CH}_{2} \mathrm{Cl}_{2}(1 \mathrm{ml})$ drop-wise. The solution was allowed to stir for 2 hours (slowly warming to $-20^{\circ} \mathrm{C}$ ). Thiol $\mathrm{R}^{2} \mathrm{SH}$ $(3 \mathrm{mmol})$ was added slowly neat via a syringe at $-20^{\circ} \mathrm{C}$ and stirred at $0^{\circ} \mathrm{C}$ for $20 \mathrm{~min}$. The reaction was quenched with a solution of $\mathrm{Na}_{2} \mathrm{~S}_{2} \mathrm{O}_{3}(0.50 \mathrm{~g}$ in $10 \mathrm{ml}$ water $)$ and saturated $\mathrm{NaHCO}_{3},(20 \mathrm{ml})$, and the mixture rapidly stirred at $0^{\circ} \mathrm{C}$ for 20 minutes before being extracted with $\mathrm{CH}_{2} \mathrm{Cl}_{2}(3 \times 50 \mathrm{ml})$. The combined organic extracts were dried over anhydrous $\mathrm{MgSO}_{4}$, filtered and evaporated under reduced pressure. The crude residue was purified by column chromatography ( $40 \mathrm{~g}$ silica) with petroleum ether-ethyl acetate mixtures.

Compound $3(0.391 \mathrm{~g}, 91 \%)$ was obtained as a pale yellow oil; IR $v_{\max }\left(\mathrm{CHCl}_{3}\right) / \mathrm{cm}^{-1} 496$ (S-S); $\delta_{\mathrm{H}}\left(400 \mathrm{MHz}, \mathrm{CDCl}_{3}\right): 0.96(3 \mathrm{H}, \mathrm{t}, J 7.3 \mathrm{~Hz}, \mathrm{H}-3), 1.70(2 \mathrm{H}$, sextet, $J 7.3 \mathrm{~Hz}, \mathrm{H}-2), 2.71(2 \mathrm{H}, \mathrm{t}, J$ $7.3 \mathrm{~Hz}, \mathrm{H}-1), 3.80\left(3 \mathrm{H}, \mathrm{s}, \mathrm{OCH}_{3}\right), 6.86\left(2 \mathrm{H}, \mathrm{d}, J 8.9 \mathrm{~Hz}, \mathrm{H}_{m}\right), 7.48\left(2 \mathrm{H}, \mathrm{d}, J 8.9 \mathrm{~Hz}, \mathrm{H}_{o}\right) ; \delta_{\mathrm{C}}$ $\left(100.57 \mathrm{MHz}, \mathrm{CDCl}_{3}\right): 13.1(\mathrm{C}-3), 22.1(\mathrm{C}-2), 40.9(\mathrm{C}-1), 55.4\left(-\mathrm{OCH}_{3}\right), 114.6\left(\mathrm{C}_{m}\right), 128.6\left(\mathrm{C}_{s}\right)$, 131.6 $\left(\mathrm{C}_{o}\right), 159.5\left(\mathrm{C}_{p}\right)$; HRMS: $m / z 214.0487\left(\mathrm{M}^{+}\right) . \mathrm{C}_{10} \mathrm{H}_{14} \mathrm{OS}_{2}$ requires 214.0486.

Compound $4(0.337 \mathrm{~g}, 85 \%)$ was obtained as a pale yellow oil; IR $v_{\max }\left(\mathrm{CHCl}_{3}\right) / \mathrm{cm}^{-1} 488$ (S-S); $\delta_{\mathrm{H}}\left(400 \mathrm{MHz}, \mathrm{CDCl}_{3}\right): 0.97(3 \mathrm{H}, \mathrm{t}, J 7.3 \mathrm{~Hz}, \mathrm{H}-3), 1.70(2 \mathrm{H}$, sextet, $J 7.3 \mathrm{~Hz}, \mathrm{H}-2), 2.34(3 \mathrm{H}, \mathrm{s}$, $\left.\mathrm{CH}_{3}\right), 2.71(2 \mathrm{H}, \mathrm{t}, J 7.3 \mathrm{~Hz}, \mathrm{H}-1), 7.13\left(2 \mathrm{H}, \mathrm{d}, J 8.1 \mathrm{~Hz}, \mathrm{H}_{m}\right), 7.43\left(2 \mathrm{H}, \mathrm{d}, J 8.1 \mathrm{~Hz}, \mathrm{H}_{o}\right) ; \delta_{\mathrm{C}}$ (100.57 MHz, $\left.\mathrm{CDCl}_{3}\right)$ : 13.1 (C-3), $21.0\left(\mathrm{Ar}_{-} \mathrm{CH}_{3}\right), 22.2(\mathrm{C}-2), 40.9(\mathrm{C}-1), 128.4\left(\mathrm{C}_{m}\right), 129.7\left(\mathrm{C}_{o}\right)$, 134.5 $\left(\mathrm{C}_{s}\right), 137.1\left(\mathrm{C}_{p}\right)$; HRMS: $m / z$ 198.0511 $\left(\mathrm{M}^{+}\right) . \mathrm{C}_{10} \mathrm{H}_{14} \mathrm{~S}_{2}$ requires 198.0537.

Compound $5(0.393 \mathrm{~g}, 82 \%)$ was obtained as a pale yellow oil; IR $v_{\max }\left(\mathrm{CHCl}_{3}\right) / \mathrm{cm}^{-1} 488(\mathrm{~S}-\mathrm{S})$; $\delta_{\mathrm{H}}\left(300 \mathrm{MHz}, \mathrm{CDCl}_{3}\right): 0.91(3 \mathrm{H}, \mathrm{t}, J 6.8 \mathrm{~Hz}, \mathrm{H}-6), 1.25-1.44(6 \mathrm{H}, \mathrm{m}, \mathrm{H}-3, \mathrm{H}-4, \mathrm{H}-5), 1.70(2 \mathrm{H}$, quintet, $J 7.4 \mathrm{~Hz}, \mathrm{H}-2), 2.36\left(3 \mathrm{H}, \mathrm{s}, \mathrm{CH}_{3}\right), 2.76(2 \mathrm{H}, \mathrm{t}, J 7.4 \mathrm{~Hz}, \mathrm{H}-1), 7.15(2 \mathrm{H}, \mathrm{d}, J 7.8 \mathrm{~Hz}$, $\left.\mathrm{H}_{m}\right), 7.46\left(2 \mathrm{H}, \mathrm{d}, J 7.8 \mathrm{~Hz}, \mathrm{H}_{o}\right) ; \delta_{\mathrm{C}}\left(100.57 \mathrm{MHz}, \mathrm{CDCl}_{3}\right): 14.0(\mathrm{C}-6), 21.0\left(\mathrm{CH}_{3}\right), 22.6(\mathrm{C}-5)$, 28.2 (C-4), 28.8 (C-2), $31.4(\mathrm{C}-3), 39.0(\mathrm{C}-1), 128.4\left(\mathrm{C}_{m}\right), 129.7\left(\mathrm{C}_{o}\right), 134.4\left(\mathrm{C}_{s}\right), 136.9\left(\mathrm{C}_{p}\right)$; HRMS: $m / z 240.1010\left(\mathrm{M}^{+}\right) . \mathrm{C}_{13} \mathrm{H}_{20} \mathrm{~S}_{2}$ requires 240.1006 .

Compound $6(0.461 \mathrm{~g}, 90 \%)$ was obtained as a clear oil; IR $v_{\max }\left(\mathrm{CHCl}_{3}\right) / \mathrm{cm}^{-1} 487$ (S-S), 1710 $(\mathrm{C}=\mathrm{O}) ; \delta_{\mathrm{H}}\left(400 \mathrm{MHz}, \mathrm{CDCl}_{3}\right): 1.32\left(9 \mathrm{H}, \mathrm{s},\left(\mathrm{H}-2^{\prime}\right), 3.95\left(3 \mathrm{H}, \mathrm{s}, \mathrm{OCH}_{3}\right), 7.19(1 \mathrm{H}, \mathrm{m}, \mathrm{H}-5), 7.49\right.$ $(1 \mathrm{H}, \mathrm{m}, \mathrm{H}-4), 7.97(1 \mathrm{H}, \mathrm{dd}, J 8.1 \mathrm{~Hz}$ and $1.2 \mathrm{~Hz}, \mathrm{H}-6), 8.22(1 \mathrm{H}, \mathrm{dd}, J 8.1 \mathrm{~Hz}$ and $1.2 \mathrm{~Hz}, \mathrm{H}-3)$; $\delta_{\mathrm{C}}\left(100.57 \mathrm{MHz}, \mathrm{CDCl}_{3}\right): 30.0\left(\mathrm{C}-2^{\prime}\right), 49.2\left(\mathrm{C}-1{ }^{\prime}\right), 52.1\left(\mathrm{OCH}_{3}\right), 124.9(\mathrm{C}-5), 126.5(\mathrm{C}-3), 127.1$ (C-1), 131.1 (C-6), 132.2 (C-4), 142.9 (C-2), 166.8 (C=O); HRMS: m/z $256.0597\left(\mathrm{M}^{+}\right)$. $\mathrm{C}_{12} \mathrm{H}_{16} \mathrm{O}_{2} \mathrm{~S}_{2}$ requires 256.0592 .

Compound $7\left(0.404 \mathrm{~g}, 88 \%\right.$ ) was obtained as a pale yellow oil; IR $v_{\max }\left(\mathrm{CHCl}_{3}\right) / \mathrm{cm}^{-1} 468$ (S-S), $1340\left(\mathrm{NO}_{2}\right), 1515\left(\mathrm{NO}_{2}\right) ; \delta_{\mathrm{H}}\left(300 \mathrm{MHz}, \mathrm{CDCl}_{3}\right): 0.99(3 \mathrm{H}, \mathrm{t}, J 7.2 \mathrm{~Hz}, \mathrm{H}-3), 1.69(2 \mathrm{H}$, sextet, $J$ $7.2 \mathrm{~Hz}, \mathrm{H}-2), 2.74(2 \mathrm{H}, \mathrm{t}, J 7.4 \mathrm{~Hz}, \mathrm{H}-1), 7.65\left(2 \mathrm{H}, \mathrm{d}, J 8.7 \mathrm{~Hz}, \mathrm{H}_{o}\right), 8.16\left(2 \mathrm{H}, \mathrm{d}, J 8.7 \mathrm{~Hz}, \mathrm{H}_{m}\right)$; $\delta_{\mathrm{C}}\left(75.45 \mathrm{MHz}, \mathrm{CDCl}_{3}\right): 13.0(\mathrm{C}-3), 22.3(\mathrm{C}-2), 41.0(\mathrm{C}-1), 123.9\left(\mathrm{C}_{o}\right), 125.7\left(\mathrm{C}_{m}\right), 146.1\left(\mathrm{C}_{s}\right)$, $147.3\left(\mathrm{C}_{p}\right)$; HRMS: $m / z 229.0239\left(\mathrm{M}^{+}\right) . \mathrm{C}_{9} \mathrm{H}_{11} \mathrm{NO}_{2} \mathrm{~S}_{2}$ requires 229.0231 . 
Compound $8(0.311 \mathrm{~g}, 84 \%)$ was obtained as a yellow oil; IR $v_{\max }\left(\mathrm{CHCl}_{3}\right) / \mathrm{cm}^{-1} 478(\mathrm{~S}-\mathrm{S})$; $\delta_{\mathrm{H}}$ (400 MHz, $\left.\mathrm{CDCl}_{3}\right): 1.00$ (3H, t, J 7.4 Hz, H-3'), 1.73 (2H, sextet, J 7.3 Hz, H-2'), 2.78 (2H, t, $J$ 7.4, Hz, H-1'), 7.07 (1H, m, H-5), 7.64 (1H, td, J 7.6 Hz and 1.6 Hz, H-4), 7.74 (1H, dt, J 7.6 and $0.8 \mathrm{~Hz}, \mathrm{H}-3), 8.46(1 \mathrm{H}, \mathrm{m}, \mathrm{H}-6)$; $\delta_{\mathrm{C}}\left(\mathrm{MHz}_{\mathrm{CDCl}}\right)$ : 13.0 (C-3'), 22.3 (C-2'), 41.0 (C-1'), 119.6 (C-3), 120.4 (C-5), 136.9 (C-4), 149.5 (C-6), 161.4 (C-2); HRMS: m/z 185.0339 (M ). $\mathrm{C}_{8} \mathrm{H}_{11} \mathrm{NS}_{2}$ requires 185.0333 .

\section{The thiosulfinates were synthesized using the following method}

To a stirred solution of the unsymmetrical disulfide $(2 \mathrm{mmol})$ in $\mathrm{CH}_{2} \mathrm{Cl}_{2}(5 \mathrm{ml})$ under $\mathrm{N}_{2}$ at $-78^{\circ} \mathrm{C}$ was added $m$-CPBA ( $2 \mathrm{mmol}, 1.0 \mathrm{eq})$. The reaction was allowed to stir for 3 hours slowly warming to $0^{\circ} \mathrm{C}$, then quenched with saturated aqueous $\mathrm{NaHCO}_{3}(20 \mathrm{ml})$ and extracted with $\mathrm{CH}_{2} \mathrm{Cl}_{2}(3 \mathrm{x} 50 \mathrm{ml})$. The combined organic extracts were dried over anhydrous $\mathrm{MgSO}_{4}$, filtered and evaporated under reduced pressure. The crude material was purified by chromatography as before.

Compound 3a $(66 \%)$ was obtained as a pale yellow oil; IR $v_{\max }\left(\mathrm{CHCl}_{3}\right) / \mathrm{cm}^{-1} 1079(\mathrm{~S}=\mathrm{O}$ stretch); $\delta_{\mathrm{H}}\left(400 \mathrm{MHz}, \mathrm{CDCl}_{3}\right): 1.09(3 \mathrm{H}, \mathrm{t}, J 7.4 \mathrm{~Hz}, \mathrm{H}-3), 1.88(2 \mathrm{H}, \mathrm{m}, \mathrm{H}-2), 3.04$ (2H, m, H1), $3.83\left(3 \mathrm{H}, \mathrm{s}, \mathrm{OCH}_{3}\right), 6.93\left(2 \mathrm{H}, \mathrm{d}, J 8.8 \mathrm{~Hz}, \mathrm{H}_{m}\right), 7.53\left(2 \mathrm{H}, \mathrm{d}, J 8.8 \mathrm{~Hz}, \mathrm{H}_{o}\right) ; \delta_{\mathrm{C}}(100.57 \mathrm{MHz}$, $\left.\mathrm{CDCl}_{3}\right): 13.2(\mathrm{C}-3), 17.2(\mathrm{C}-2), 55.4\left(\mathrm{OCH}_{3}\right), 57.7(\mathrm{C}-1), 115.0\left(\mathrm{C}_{m}\right), 119.2\left(\mathrm{C}_{s}\right), 137.3\left(\mathrm{C}_{o}\right)$, $161.6\left(\mathrm{C}_{p}\right)$; HRMS: $m / z 230.0440\left(\mathrm{M}^{+}\right) . \mathrm{C}_{10} \mathrm{H}_{14} \mathrm{O}_{2} \mathrm{~S}_{2}$ requires 230.0435 .

Compound 4a (54\%) was obtained as a pale yellow oil; IR $v_{\max }\left(\mathrm{CHCl}_{3}\right) / \mathrm{cm}^{-1} 1086(\mathrm{~S}=\mathrm{O}$ stretch); $\delta_{\mathrm{H}}\left(400 \mathrm{MHz}, \mathrm{CDCl}_{3}\right): 1.09(3 \mathrm{H}, \mathrm{t}, J 7.6 \mathrm{~Hz}, \mathrm{H}-3), 1.89(2 \mathrm{H}, \mathrm{m}, \mathrm{H}-2), 2.38\left(3 \mathrm{H}, \mathrm{s}, \mathrm{CH}_{3}\right)$, $3.07(2 \mathrm{H}, \mathrm{m}, \mathrm{H}-1), 7.22\left(2 \mathrm{H}, \mathrm{d}, J 8.0 \mathrm{~Hz}, \mathrm{H}_{m}\right), 7.49\left(2 \mathrm{H}, \mathrm{d}, J 8.0 \mathrm{~Hz}, \mathrm{H}_{o}\right)$; $\delta_{\mathrm{C}}(100.57 \mathrm{MHz}$, $\left.\mathrm{CDCl}_{3}\right): 13.2(\mathrm{C}-3), 17.3\left(\mathrm{CH}_{3}\right), 21.3(\mathrm{C}-2), 57.9(\mathrm{C}-1), 125.6\left(\mathrm{C}_{s}\right), 130.3\left(\mathrm{C}_{m}\right), 135.3\left(\mathrm{C}_{o}\right), 140.7$ $\left(\mathrm{C}_{p}\right)$; HRMS: $m / z 214.0478\left(\mathrm{M}^{+}\right) . \mathrm{C}_{10} \mathrm{H}_{14} \mathrm{OS}_{2}$ requires 214.0486 .

Compound 5a (70\%) was obtained as a pale yellow oil; IR $v_{\max }\left(\mathrm{CHCl}_{3}\right) / \mathrm{cm}^{-1} 1087(\mathrm{~S}=\mathrm{O}$ stretch); $\delta_{\mathrm{H}}\left(400 \mathrm{MHz}, \mathrm{CDCl}_{3}\right): 0.89$ (3H, m, H-6), 1.30-1.48 (6H, m, H-3, H-4, H-5), 1.83 (2H, m, H-2), $2.36\left(3 \mathrm{H}, \mathrm{s}, \mathrm{CH}_{3}\right), 3.07(2 \mathrm{H}, \mathrm{t}, J 7.6 \mathrm{~Hz}, \mathrm{H}-1), 7.20\left(2 \mathrm{H}, \mathrm{d}, J 8.0 \mathrm{~Hz}, \mathrm{H}_{m}\right), 7.48(2 \mathrm{H}, \mathrm{d}, J$ $\left.8.0 \mathrm{~Hz}, \mathrm{H}_{o}\right) ; \delta_{\mathrm{C}}\left(100.57 \mathrm{MHz}, \mathrm{CDCl}_{3}\right)$ : $13.9(\mathrm{C}-6), 21.3\left(\mathrm{CH}_{3}\right), 22.4(\mathrm{C}-5), 23.5(\mathrm{C}-4), 28.3(\mathrm{C}-2)$, 31.2 (C-3), $56.1(\mathrm{C}-1), 125.6\left(\mathrm{C}_{s}\right), 130.3\left(\mathrm{C}_{m}\right), 135.3\left(\mathrm{C}_{o}\right), 140.6\left(\mathrm{C}_{p}\right)$; HRMS: $m / z 256.0933$ $\left(\mathrm{M}^{+}\right) . \mathrm{C}_{13} \mathrm{H}_{20} \mathrm{OS}_{2}$ requires 256.0956 .

\section{$\mathrm{X}$-ray analysis}

A single crystal of dimensions $0.30 \times 0.30 \times 0.30 \mathrm{~mm}$ was mounted on a Nonius Kappa CCD diffractometer for intensity data-collection with $\mathrm{MoK}_{\alpha} \mathrm{X}$-rays $(\lambda=0.71073 \AA)$. The crystal was cooled to $113 \pm 2 \mathrm{~K}$ in a stream of nitrogen vapour to enhance diffraction quality and data were collected using $\phi$ - and $\omega$-scans of 1.0 and $1.2^{\circ}$ (program COLLECT ${ }^{14}$ ). Unit cell refinement and data reduction were performed with DENZO-SMN ${ }^{15}$ and the structure was solved by isomorphous replacement using the rigid skeleton of the host molecule of the TRIMEB.(Z)ajoene complex as a trial model. ${ }^{12}$ All remaining non-H atoms of the host and guest were located in successive difference electron-density maps. All but one of the host atoms refined anisotropically. The phenyl ring of the guest molecule was modelled as a regular hexagon with a common variable isotropic thermal parameter. One of the sulfur atoms refined anisotropically 
while the remaining guest atoms were treated isotropically. Full-matrix least-squares refinement on $F^{2}$ was performed using the program SHELXL- $97^{16}$ with weights of the form $\mathrm{w}=\left[\sigma^{2}\left(\mathrm{~F}_{\mathrm{o}}{ }^{2}\right)+\right.$ $(\mathrm{aP})^{2}+\mathrm{bP}^{-1}$ and $\mathrm{P}=\left[\max \left(\mathrm{F}_{\mathrm{o}}^{2}, 0\right)+2 \mathrm{~F}_{\mathrm{c}}^{2}\right] / 3$. The configuration at the stereogenic sulfur atom was found to be $(S-)$. The largest peak in the final difference electron-density map was located at 1.9 $\AA$ from this centre, its position suggesting the presence of a trace of the ( $R$-)-enantiomer. However, the latter could not be modelled due to its low site-occupancy.

\section{References}

1. Ariga, T.; Seki, T. BioFactors 2006, 26, 93.

2. Ankri, S.; Mirelman, D. Microbes and Infection 1999, 1, 125.

3. Cutler, R. R.; Wilson, P. Brit. J. Biomed. Sci. 2004, 61, 71.

4. Weber, N. D.; Andersen, D. O.; North, J. A.; Murray, B. K.; Lawson, L. D.; Hughes, B. G. Planta Med. 1992, 58, 417.

5. (a) Cavallito, C. J.; Buck, J. S.; Suter, C. M. J. Am. Chem. Soc., 1944, 66, 1952. (b) Miron, T.; Rabinkov, A.; Mirelman, D.; Wilchek, M.; Weiner, L. Biochim. Biophys. Acta. Biomembr. 2000, 1463, 20. (c) Giles, G. I.; Tasker, K. M.; Jacob, C. Gen. Physiol. Biophys. 2002, 21, 65. (d) Ovsejevi, K.; Grazu, V.; Cuadra, K.; Batista-Viera, F. Enzyme Microb. Technol. 2004, 35, 203.

6. (a) Block, E.; Weidman, S. W. J. Am. Chem. Soc., 1973, 95, 5046. (b) Block, E.; O'Connor, J. J. Am. Chem. Soc., 1974, 96, 3929. (c) Block, E.; Ahmad, S.; Catalfamo, J. L.; Jain, M. K.; Apitz-Castro, R. J. Am. Chem. Soc., 1986, 108, 7045.

7. Hassan, H. T. Leukemia. Res. 2004, 28, 667.

8. (a) Kice, J. L.; Venier, C. G.; Large, G. B.; Heasley, L. J. Am. Chem. Soc., 1969, 91, 2028.

(b) Koch, P.; Ciuffarin, E.; Fava, A. J. Am. Chem. Soc., 1970, 92, 5971.

9. Brace, N. O. J. Fluorine. Chem. 2000, 105, 11.

10. Freeman, F.; Angeletakis C. N. J. Org. Chem. 1985, 50, 793.

11. (a) Hunter, R.; Caira, M.; Stellenboom, N. Ann. N.Y. Acad. Sci. 2005, 1056, 234. (b) Hunter, R.; Caira, M.; Stellenboom, N. J. Org. Chem. 2006, 71, 8268. (c) Benati, L.; Montevecchi, P. C.; Spagnolo, P. Tetrahedron Lett. 1986, 27, 1739. (d) Dubs, P.; Stuessi, R. Helv. Chim. Acta 1976, 59, 1307.

12. Caira, M. R.; Hunter, R.; Bourne, S. A.; Smith, V. J. Supramol. Chem., 2004, 16, 395.

13. (a) Allen, P. Jr.; Brook, J. W. J. Org. Chem. 1962, 27, 1019. (b) Field, L.; Lacefield, W.B.J. Org. Chem. 1966, 31, 3555. (c) Chang, H. S.; Yong, G. H.; Kim, Y. H. Bull. Korean Chem. Soc., 1985, 6, 381.

14. Hooft, R. COLLECT, 1998, Nonius B.V., Delft, The Netherlands.

15. Otwinowski, Z.; Minor, W. Methods Enzymol. 1997, 276, 307.

16. Sheldrick, G.M. SHELXL-97 1997, (University of Göttingen, Germany). 